\title{
Dampak Ekonomi dari Ihtikar dan Siyasah Al-Ighraq dalam Konsep Jual Beli
}

\author{
PUTRI NURAINI
}

Fakultas Agama Islam (FAI) Universitas Islam Riau (UIR), Jl. Kaharuddin Nasution No.113,Perhentian Marpoyan, Pekanbaru 28284,Email : putrinuraini@fis.uir.ac.id

\begin{abstract}
In Islam, the concept of buying and selling must be based on values and ethics derived from the basic values of religion that uphold honesty and justice. The existence of this discussion is related to the concept of buying and selling that is prohibited in Islam including ihtikâr and siyasa al-ighraq. Ihtikâr is the practice of hoarding goods so that the goods circulating in the community are reduced, then the price rises, which the hoarder has a large profit, while the community is disadvantaged. While siyasa al-ighraq (dumping/ price dropping) is a trading activity that aims to make a profit by selling goods at a price lower than the prevailing market price and in practice can lead to unhealthy competition and can disrupt the stability of market prices. In economics, the practice of ihtikâr and siyasa al-ighraq are often carried out by business actors in seizing economic markets, this will have an impact on the economy that is causing unhealthy competition and will ultimately result in disruption of market mechanisms. Therefore, Islam forbids the perpetrators of ihtikâr and siyasa al-ighraq and they belong to the category of buying and selling that is prohibited in Islam.
\end{abstract}

Keywords: Ihtikâr, Siyasah al-Ighraq, Concept of Buying and Selling, Economy

\begin{abstract}
Abstrak: Dalam Islam, konsep jual beli harus dilandasi nilai-nilai dan etika yang bersumber dari nilai-nilai dasar agama yang menjunjung tinggi tentang kejujuran dan keadilan. Adanya pembahasan ini terkait dengan konsep jual beli yang dilarang dalam Islam diantaranyayaitu ihtikâr dan siyasah alighraq.Ihtikâr merupakan praktik menimbun barang agar barang yang beredar dimasyarakat berkurang, lalu harganya naik, yang menimbun memperoleh keuntungan besar, sedangkan masyarakat dirugikan. Sedangkansiyasah alighraq (dumping/banting harga) adalah aktivitas perdagangan yang bertujuan untuk mencari keuntungan dengan jalan menjual barang pada tingkat harga yang lebih rendah dari harga yang berlaku dipasarandan dalam
\end{abstract}


praktiknyadapat menimbulkan persaingan yang tidak sehat serta dapat mengacaukan stabilitas harga pasar. Dalam ekonomi, praktik ihtikâr dan siyasah al-ighraq seringkali dilakukan oleh pelaku usaha dalam merebut pasar ekonomi, hal ini akan berdampak terhadap ekonomi yaitu menimbulkan persaingan yang tidak sehat dan pada akhirnyaakan mengakibatkan terganggunya mekanisme pasar. Oleh karena itu, Islammelarang pelaku ihtikâr dan siyasah al-ighraq dan termasuk kedalam kategori jual beli yang dilarang dalam Islam.

Kata kunci: Ihtikâr, Siyasah al-Ighraq, KonsepJual Beli, Ekonomi.

\section{PENDAHULUAN}

Mu'amalah adalah satu aspek dari ajaran yang telah melahirkan peradaban Islam yang maju di masa lalu. Mu'amalah merupakan satu bagian dari syari'at Islam, yaitu yang mengatur kehidupan manusia dalam hubungan dengan manusia, masyarakat dan alam. Karena mu'amalah merupakan aspek dari ajaran Islam, maka ia juga mengandung aspek teologis dan spiritual. Aspek inilah yang merupakan dasar dari mu'amalah tersebut.Masalah mu'amalah yang sering mewarnai kehidupan kita sehari-hari banyak ragamnya, antara lain: jual beli, khiyar, pinjam meminjam, utang piutang, pemberian, titipan daln lainnya (Hamid, 2017). Manusia sebagai makhluk sosial yang diciptakan Allah Subhanahu wa Ta'ala yang saling membutuhkan satu dengan yang lain tak lepas dalam urusan jual beli guna memenuhi kebutuhan hidupnya. Jual beli juga merupakan aktivitas sehari-hari setiap orang untuk memenuhi kebutuhan kehidupannya, dan setiap orang yang terjun dalam bidang jual beli harus mengetahui hukum jual beli agar jual beli tersebut tidak ada yang dirugikan, yang sesuai dengan syariat Islam.

Islam melihat konsep jual beli sebagai suatu alat untuk menjadikan manusia itu semakin dewasa dalam berpola pikir dan melakukan berbagai aktivitas, termasuk aktivitas ekonomi. Pasar sebagai tempat aktivitas jual beli harus dijadikan sebagai tempat pelatihan yang tepat bagi manusia sebagai khalifah dimuka bumi. Maka sebenarnya jual beli dalam Islam merupakan wadah untuk memproduksi khalifah-khalifah yang tangguh dimuka bumi.

Masalah ekonomi yang dihadapi masyarakat secara prinsip berbeda-beda, baik sebab-sebab timbulnya masalah ekonomi yang berakibat metode merumuskan keputusannya pun berbeda, keputusan ini akan menentukan araharah kebijakan ekonomi namun penyebab yang sering kali timbul secara dominan adalah faktor kebijakan (policy) ekonomi yang menjadi penyebab timbulnya masalah ekonomi.

Dalam pandangan Islam jual beli merupakan sarana untuk beribadah kepada Allah dan merupakah fardlu kifayah, oleh karena itu bisnis dan perdagangan (jual beli) tidak boleh lepas dari peran Syari'ah Islamiyah. Sistem Islam melarang setiap aktivitas perekonomian, tak terkecuali jual beli (perdagangan) yang mengandung unsur paksaan, mafsadah (lawan dari manfaat), gharar (penipuan), ihtikâr (penimbunan) dan siyasah al-ighraq (dumping/banting harga) pada masa modern sekarang ini. 
Sedangkan, bentuk perdagangan Islam mengijinkan adanya sistem kerja sama (patungan) atau lazim disebut dengan syirkah. Pada dasarnya, jual beli juga harus terbebas dari unsur-unsur dharar (bahaya), jahalah (ketidakjelasan) dan zhulm (merugikan atau tidak adil terhadap salah satu pihak) (Qusthoniah, 2014).

Dalam kaitannya dengan jual beli yang dilarang dalam Islam dan berdampak pada ekonomi, hal ini yang melatarbelakangi adanya pembahasan ini, dimana akan dibahas konsep jual beli yang dilarang seperti ihtikâr (penimbunan) dan siyasah al-ighraq (dumping) serta dampaknya terhadap ekonomi pada saat sekarang ini.

\section{LANDASAN TEORI \\ Ihtikâr (penimbunan barang)}

Ihtikâr berasal dari kata hakara yang yang mengacu pada makna az-zulm (ظلمه) (Munawwir, 1997) yang berarti menganiaya dan isa'ah al-mu'asyarah (merusak pergaulan). Dengan timbangan ihtakara, yahtakiru, ihtikâr, kata ini berarti upaya penimbunan barang dagangan untuk menunggu melonjaknya harga (Haroen, 2007).Menurut Imam asySyaukani dalam Haroen (2007)ihtikâr adalah penimbunan/ penahanan barang dagangan dari peredarannya.Jadi dapat diartikan bahwa ihtikâr adalah menimbun barang agar barang yang beredar dimasyarakat berkurang, lalu harganya naik, yang menimbun memperoleh keuntungan besar, sedangkan masyarakat dirugikan.

Ihtikâr sering kali diterjemahkan sebagai monopoli dan/atau penimbunan. padahal sebenarnya ihtikâr tidak identik dengan monopoli dan/ atau penimbunan. Dalam Islam, siapapun boleh berbisnis tanpa peduli apakah dia satu-satunya penjual (monopoli) atau ada penjual lain. Menyimpan stock barang untuk keperluan persediaan pun tidak dilarang dalam Islam. Jadi monopoli sah-sah saja. Demikian pula menyimpan persediaan. Yang dilarag adalah ihtikâr, yaitu mengambil keuntungan diatas keuntungan normal dengan cara menjual lebih sedikit barang untuk harga yang lebih tinggi, atau istilah ekonominya monopoly's rent-seeking. Jadi dalam Islam monopoli boleh, sedangkan monopoly's rent-seeking tidak boleh (Karim, 2008).

Ihtikâr disebut juga rekayasa pasar dalam supply (penawaran). Rekayasa pasar dalam supply terjadi bila seorang produsen/penjual mengambil keuntungan di atas keuntungan normal dengan cara mengurangi supply agar harga produk yang dijualnya naik. Ihtikâr biasanya dilakukan dengan membuat entry barrier, yakni menghambat produsen/ penjual lain masuk ke pasar, agar ia menjadi pemain tunggal di pasar (monopoli). Karena itu, biasanya orang menyamakan ihtikâr dengan monopoli dan penimbunan, padahal tidak selalu seorang monopolis melakukan ihtikâr.

Menurut Yahya bin Umar,dalam Iskandar tentang monopoly's rent-seeking (ihtikâr) dan dumping (siyasah al-ighraq). Kedua hal tersebut dapat mengakibatkan terganggunya mekanisme pasar, di mana penjual akan menjual sedikit barang dagangannya, sementara permintaan terhadap barang tersebut sangat banyak, sehingga di pasar terjadi kelangkaan barang. Jadi, akibat ihtikâr masyarakat akan dirugikan oleh ulah sekelompok kecil manusia. Oleh karena itu, dalam pasar monopoli seorang produsen dapat bertindak sebagai price maker (penentu harga). 
Ada beberapa artikel dan jurnal yang menjelaskan makna ihtikâr secara universal. Untuk dapat memahami makna ihtikâr berikut ini disajikan pengertiannya, yaitu diantaranya: Subhan (2015) monopoli atau ihtikâr adalah menimbun barang agar yang beredar dimasyarakat berkurang, lalu harganya naik. MenurutSyaikh Abdurrahman dalam Mirza dan Qudsi (2016) menjelaskan terdapat terdepat beberapa definisi yang diberikan oleh ulama tentang ihtikâr adalah: (1) Muhammad bin Ali Syaukani, mendifinisikan ihtikâr sebagai penimbunan atau penahanan barang dagangan dari peredarannya; (2) Muhammad bin Muhammad Ghazali, mendefinisikan ihtikâr sebagai penyimpanan barang dagangan oleh penjual makanan, untuk menunggu melonjaknya harga, dan penjualannya dilakukan, ketika harga naik; dan (3) Ulama mazhab Maliki, menyatakan bahwa ihtikâr adalah penyimpanan barang oleh prodeusen baik makanan, pakaian, dan segala jenis barang yang dibutuhkan masyarakat luas, karena dapat berpotensi merusak pasar.

Dari ketiga definisi tersebut, ihtikâr memiliki beberapa persamaan yaitu adanya upaya pedagang untuk menimbun barang dagangan, agar langka dipasaran, kemudian hendak dijual pada saat harga barang tersebut melonjak naik.

Dasar hukum dari pelarangan ihtikâr, yang dikemukakan para ulama fiqih yang tidak membolehkannya adalah hasil induksi dari nilai-nilai universal yang dikandung al-Quran yang menyatakan bahwa setiap perbuatan aniaya, termasuk didalamnya ihtikâr, diharamkan.Allah SWT berfirman:

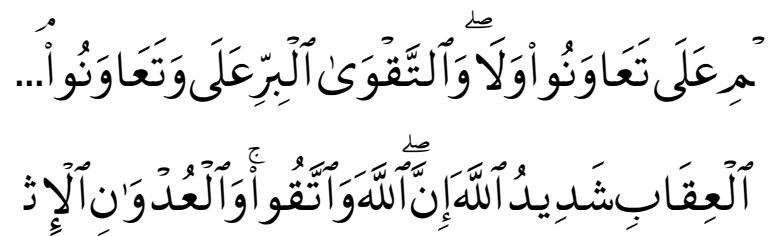

Artinya:“...dan tolong-menolonglah kamu dalam (mengerjakan) kebajikan dan taqwa, dan jangan tolongmenolong dalam berbuat dosadan pelanggaran. dan bertakwalah kamu kepada Allah, Sesungguhnya Allah amat berat siksa-Nya."(Q.S. Al-Mai'dah, 5: 2).

Sabda Rasulullah Shallallahu 'Alaihi wa Sallam yang diriwayatkan oleh Ibn Majah dari Abi Hurairah yang mengatakan :

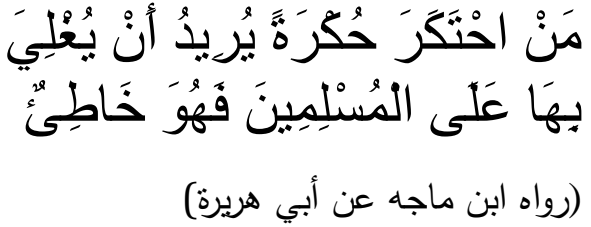

Artinya:"Siapa yang melakukan penimbunan barang dengan tujuan merusak harga pasar, sehingga harga naik secara tajam, maka ia telah berbuat salah".

Kemudian hadis Rasulullah Shallallahu 'Alaihi wa Sallam yang lainnya tidak membenarkan perbuatanihtikâr, misalnya, "Siapa yang merusak harga pasar, sehingga harga tersebut melonjak tajam, maka Allah akan menempatkannya didalam api neraka pada hari kiamat." (HR. ath-Tabrani dari Ma'qil ibn Yasar).

Berdasarkan pada ayat-ayat alQuran dan Sunnah Rasulullah Shallallahu 'Alaihi wa Sallam diatas, para ulama fiqih sepakat meyatakan bahwa ihtikâr tergolong kedalam perbuatan yang dilarang (haram). Secara tegas dikatakan 
bahwa ihtikâr (menimbun barang makanan untuk di jual pada masa sulit dengan harga yang tinggi) hukumnya haram (Syaikh al-'Allamah, 2004).Menurut Madzhab Hanafi, asySyafi'i dan Hanbali, objek barang yang haram ditimbunadalah makanan pokok yang menjadi kebutuhan umum, baik itu berupa makanan pokok manusia atau makanan pokok untuk hewan ternak. Sedangkan untuk selain makanan pokok, hukum menimbunnya tidaklah diharamkan. Namun menurut mazhab Maliki, objek ihtikâr mutlak apapun jenis barangnya. Tidak disebutkan bahwa objeknya adalah makanan saja, maka apapun jenis barang yang menjadi kebutuhan orang banyak haram ditimbun (Tarmizi, 2014).

Menurut Huzaimah dalam Mirza dan Qudsi (2016), Ahli fiqih berpendapat bahwaihtikâr (penimbunan) menjadi terlarang atau diharamkan apabila terdapat syarat sebagi berikut: (1) Penimbunan itu dilakukan pada saat manusia sangat mebutuhkan berang yang ia timbun, semisal: sembako, bahan bakar, tanah dan barang kebutuhan lainnya. Dalam hal ini, bila barang yang dimiliki pedagang tidak manyangkut kebutuhan utama (primer) konsumen, maka tidak dianggap sebagai penimbunan, karena tidak mengakibatkan kesulitan bagi manusia; (2) Barang yang diperjual belikan adalah bahan pokok yang ditimbundari suatu tanggungan persediaan nafkah untuk dirinya sendiri dan keluarganya dalam tenggang waktu selama satu tahun; dan (3) Barang-barang yang ditimbunnya itu dalam usaha menunggu saat naiknya harga, sehingga barang tersebut dapat dijual dengan harga yang lebih tinggi dan dapat memberatkan konsumen tersebut.
Dari ketiga syarat tersebut dapat dianalisa aspek keharammnya yaitu tehadap barang kelebihan nafkah dari dirinya dan keluarganya dalam masa satu tahun, yang berarti jika ia menimbun barang konsumsi untuk kebutuhan hidup keluarga dan dirinya selama satu tahun tidaklah diharamkan, sebab hal ini adalah wajar untuk menghindari kesulitan ekonomi dimusim paceklik, kemudian pengharaman terhadap barang dengan dalih ingin memperoleh keuntungan yang berlipat ganda, sebab bila tidak ditimbun, keuntungan yang didapatkan cenderung kecil dan penimbun ini dapat merusak harga dipasaran, yaitu dari harga yang rendah menjadi harga yang lebih tinggi, diutamakan sebagai bahan kebutuhan primer (sembako) dan tidak menyinggung tentang kebutuhan tersier (pelengkap).

\section{Siyasah al-Ighraq (dumping/banting harga)}

Siyasah al-Ighraq atau banting harga (politik dumping) adalah aktivitas perdagangan yang bertujuan untuk mencari keuntungan dengan jalan menjual barang pada tingkat harga yang lebih rendah dari harga yang berlaku dipasaran. Dumping terjadi bila para produsen (biasanya para pelaku monopoli) dari sutu negeri menjual hasil mereka ke negeri lain dibawah harga yang dikenakan pada para konsumen negeri asal (Mannan, 1997).Bentuk diskriminasi harga yang biasa dilakukan dikenal dengan istilah dumping, yakni harga yang lebih rendah terhadap barangbarang yang diekspor daripada barangbarang yang sama yang dijual di pasar domestik. Dumping merupakan sebuah kebijakan perdagangan yang kontroversial dan secara luas dikenal 
sebagai sebuah praktik yang tidak fair karena menimbulkan persaingan yang tidak sehat dan merusak mekanisme pasar.

Pada dasarnya, Islam sangat menghargai mekanisme pasar dalam perdagangan. Perhargaan tersebut berangkat dari ketentuan Allah Subhanahu wa Ta'ala, bahwa perniagaan harus dilakukan secara baik dan dengan rasa suka sama. Perdagangan itu wajib dibiarkan bebas, tidak boleh dibatasi siapapun, termasuk penguasa tidak boleh ikut campur dalam pembatasan kebijaksanaan perdagangan. Rasulullah Shallallahu 'Alaihi wa Sallam bersabda, yang artinya: "Biarkanlah sebagian manusia memberikan rizki kepada sebagian yang lainya".(HR. Baihaqi).

Maksud dari hadits tersebut adalah biarkanlah lalu lintas perdagangan itu bebas diatur oleh masyarakat itu. Perdagangan seperti ini menganut sistem perdagangan bebas yang sekarang menjadi isue politik di dunia internasional. Maka dari itu terciptalah pasar bebas yang sehat, sedangkan praktik monopoli tidak diizinkan, persaingan tidak sehat, menjual dengan harga lebih murah untuk mematikan pedagang lain yang lebih lemah dilarang pula. Logikanya sangat sederhana: harga jual harus cukup untuk menutup ongkos produksi barang dalam kondisi produsen yang amat tidak menguntungkan. Dengan demikian, tidak ada alasan bagi produsen untuk tidak membawa produknya ke pasar.Menurut Mannan (1997) bisa saja tujuan banting harga atau dumpingadalah: (a) untuk menghabiskan persediaan yang berlebihan karena keliru menilai permintaan; (b) mengembangkan hubungan perdagangan baru dengan menetapkan harga yang rendah; (c) mengenyahkan pesaing pasar asing, produsen asing, atau pribumi, dan (d) memungut keuntungan sebesar-besarnya dalam perekonomian.

Para pedagang melakukan praktik siyasah al-ighraq atau banting harga (dumping) yang dapat menimbulkan persaingan yang tidak sehat serta dapat mengacaukan stabilitas harga pasar. Dalam hal ini, pemerintah berhak memerintahkan para pedagang tersebut untuk menaikkan kembali harganya sesuai dengan harga yang berlaku di pasar. Apabila mereka menolaknya, pemerintah berhak mengusir para pedagang tersebut dari pasar. Hal ini pernah dipraktikkan Umar bin al-Khattab ketika mendapati seorang pedagang kismis menjual barang dagangannya dibawah harga pasar. Ia memberikan pilihan kepada pedagang tersebut, apakah menaikkan harga sesuai dengan standar yang berlaku atau pergi dari pasar.

Apapun yang mungkin menjadi pertimbangan dumping akhirnya bertujuan untuk mencapai tatanan ekonomi yang didominasi monopoli dengan menghalau produsen pribumi maupun asing dari bidang nasional maupun internasional, karena itu mengeksploitasi massa rakyat luas. Semua hal ini bertentangan dengan kebajikan dan mereka yang turut dalam praktik demikian berusaha mengambil keuntungan dari kebutuhan dan kemelaratan sesama manusia karena itu dumping bertentangan dengan jiwa Islam (Mannan, 1997).

\section{Konsep jual beli yang dilarang dalam Islam}

Walaupun Islam mendorong umatnya untuk berdagang, bukan berarti dapat dilakukan sesuka dan sekehendak manusia, seperti lepas kendali. Adab dan 
etika bisnis dalam Islam harus dihormati dan dipatuhi jika para pedagang dan pebisnis ingin termasuk dalam golongan para Nabi, syuhada dan shadiqien.

Menurut Hamid (2017) Syaratsyarat yang telah ditetapkan dalam Islam tentang jual-beli adalah sebagai beikut: (1) Penjual dan pembelinya haruslah: (a) Baligh; (b) Berakal sehat; dan (c) Atas kehendak sndiri; (2) Uang dan bendanya haruslah: (a) Halal dan suci menurut agama; (b) Bermanfaat; (c) Keadaan barang dapat diserahterimakan; (d) Keadaan barang diketahui oleh penjual dan pembeli; dan (e) Milik sendiri; dan (3) Ijab Qabul.

Konsep Jual beli dapat dilihat dari beberapa sudut pandang, antara lain ditinjau dari segi sah atau tidak sah dan terlarang atau tidak terlarang. Kemudian konsep jual beli yang dilarang berbagai jenis sesuai dengan cabang-cabangnya dan sifatnya. Hal ini dapat dibagi kedalam: (1) Ditinjau dari sudut rusak syarat akad; dan (2) Ditinjau dari sudut rusak syarat sah (Ayob, 2008).

Menurut Prinsip Hukum Islam, yang dikutip oleh Al-Jamal (1986), sesuatu yang dihalalkan Allah untuk memilikinya, maka halal pula yang menjadi obyek perdagangan, demikian pula halnya segala bentuk barang yang diharamkan untuk memilikinya, maka haram pula memperdagangkannya. Disamping itu, dalam ketentuan hukum Islam, bahwa barang itu pada dasarnya halal, akan tetapi, karena sikap serta perbuatan para pelakunya, maka usahanya itu menjadi haram, yaitu: penimbunan barang dagangan karena penimbunan yang dilakukan itu bertujuan untuk mencari keuntungan yang lebih banyak, terutama pada saat harga itu naik.

\section{PEMBAHASAN \\ Ihtikâr dan Siyasah al-IghraqSerta Dampaknya Terhadap Ekonomi}

Aktivitas ekonomi merupakan begian yang tidak terpisahkan dari ketakwaan seorang muslim kepada Allah Subhanahu wa Ta'ala. Dalam kaitannya dengan masalah ihtikârdan siyasah alighraq, kedua istilah ini dalam ilmu ekonomi kontemporer dikenal dengan monopoly's rent-seeking (ihtikâr)dan dumping (siyasah al-ighraq).Dalam Islam, konsep ekonomi dan perdagangan harus dilandasi nilai-nilai dan etika yang bersumber dari nilai-nilai dasar agama yang menjunjung tinggi tentang kejujuran dan keadilan. Barangsiapa menjual barangnya di pasar yang kualitasnya sama seperti barang penjual lainnya. Maka ia dilarangnya untuk menjual barangnya di pasar yang kualitasnya sama seperti barang penjual lainnya. Maka ia dilarangnya untuk menjual dengan harga yang lebih rendah dari harga pasar apabila hal itu akan merusak harga pasar dan membuat resah para pelaku pasar, hal tersebut harus dihindari.

Permasalahan ihtikâr dan siyasah al-ighraq ini telah mendapat perhatian yang sangat serius dari ajaran Islam, sebagaimanafirman Allah Subhanahu wa Ta'aladalam Q.S. 59 ayat 7 yang artinya: "...agar harta itu jangan hanya berputar di kalangan orang-orang kaya di antara kamu sekalian..." (QS. 59 : 7). Selain riba, monopoli adalah komponen utama yang akan membuat kekayaan terkonsentrasi ditangan segelintir kelompok, sehingga menciptakan kesenjangan sosial dan ekonomi.

Seperti yang telah dibahas sebelumnya, bahwa ihtikâr dan siyasah alighraq hukumnya haram. Sebab kedua 
bentuk praktik ini mengandung kecurangan, ketidakadilan dan sangat membahayakan terhadap stabilitas ekonomi. Dengan adanya ihtikâr itu berarti hanya ada satu pihak yang sangat diuntungkan (dan pihak ini termasuk minoritas) dengan mengorbankan pihak mayoritas. Ini adalah masalah ketidakadilan dalam masalah ekonomi, padahal Islam memberikan porsi yang seimbang antara kepentingan umum (mayoritas) dan kepentingan pribadi (minoritas). Disamping mengandung ketidakadilan, ihtikâr juga menyebabkan krisis yang sangat fatal dan sangat mengancam stabilitas ekonomi. Ihtikâr juga menyebabkan kesulitan bagi orang lain serta menyempitkan ruang gerak mereka untuk memperoleh kebutuhannya.

Ihtikâr dapat mengakibatkan terganggunya mekanisme pasar, dimana penjual akan menjual sedikit barang dagangannya, sementara permintaan terhadap barang tersebut sangat banyak, sehingga di pasar terjadi kelangkaan barang. Berdasarkan hukum ekonomi, maka: "Semakin sedikit persediaan barang di pasar, maka harga barang semakin naik dan permintaan terhadap barang semakin berkurang." Dalam kondisi seperti ini produsen dapat menjual barangnya dengan harga yang lebih tinggi dari harga normal. Penjual akan mendapatkan keuntungan yang lebih besar dari keuntungan normal (super normal profit), sementara konsumen akan menderita kerugian. Jadi, akibat ihtikâr masyarakat akan dirugikan oleh ulah sekelompok kecil manusia. Oleh karena itu, dalam pasar monopoli seorang produsen dapat bertindak sebagai price maker (penentu harga).

Perilaku industri yang melakukan ihtikâr berdampak pada penentuan harga, kuantitas barang dan keuntungan yang dapat diperoleh oleh produsen. Hakikat ihtikâr adalah memproduksi lebih sedikit dari kemampuan produksinya untuk mendapatkan keuntungan yang lebih besar. Hal inidapat dilihat pada Gambar 1. berikut ini :

\section{Gambar 1.Ihtikâr (Monopoly's Rent Seeking Behaviour)}

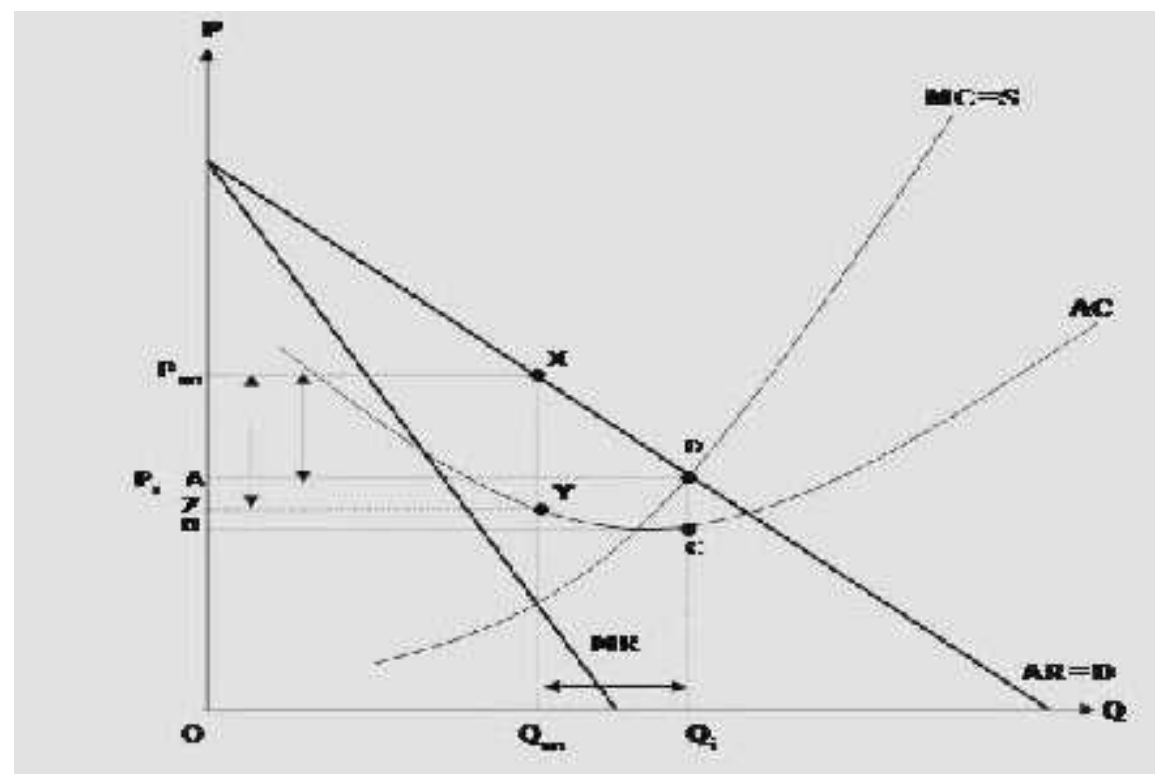


Sumber : Karim, 2006.

Pada gambar tersebut dapat dilihat sebuah contoh, kemampuan produksi industri A adalah Q1, karena industri tersebut menghadapi pasar monopoli, ada kesempatan untuk memproduksi barang agar dapat keuntungan yang maksimal. Keuntungan maksimal yang dapat diambil oleh industri yang berprilaku sebagai monopolis (melakukan ihtikâr), maka ia akan memilih tingkat produksinya ketika $\mathrm{MC}=\mathrm{MR}$, dengan jumlah $\mathrm{Q}$ sebesar $\mathrm{Q}_{\mathrm{m}}$, dan $P$ sebesar $P_{m}$. Dengan demikian, ia memproduksi lebih sedikit, dan menjual pada harga yang lebih tinggi. Profit yang dinikmati adalah sebesar kotak $\mathrm{P}_{\mathrm{m}} \mathrm{XYZ}$. Hal inilah yang dilarang karena produsen tersebut sebenarnya dapat berproduksi dengan tingkat output yang lebih tinggi yaitu $S=D$, atau ketika $\mathrm{MC}=\mathrm{AR}$. Pada tingkat ini, jumlah barang yang diproduksi lebih banyak, yakni sebesar $\mathrm{Q}_{\mathrm{i}}$, dan harganya pun lebih murah, yakni sebesar $\mathrm{P}_{\mathrm{i}}$. Tentu saja profit yang dihasilkan lebih sedikit, yakni sebesar kotak ABCD. Selisih profit antara kotak PmHYZ dengan kotak ABCD inilah yang merupakan monopoly's rent yang diharamkan (Karim, 2006).

Para pedagang melakukan praktik siyasah al-ighraq atau banting harga (dumping) yang dapat menimbulkan persaingan yang tidak sehat serta dapat mengacaukan stabilitas harga pasar. Dalam hal ini, pemerintah berhak memerintahkan para pedagang tersebut untuk menaikkan kembali harganya sesuai dengan harga yang berlaku di pasar. Apabila mereka menolaknya, pemerintah berhak mengusir para pedagang tersebut dari pasar. Kemudian Siyasah al-Ighraq (dumping) yang dilakukan oleh seseorang dengan maksud agar para saingan dagangnya mengalami kebangkrutan. Dengan demikian ia akan leluasa menentukan harga di pasar. Siyasah al-ighraq atau banting harga (dumping) dapat menimbulkan persaingan yang tidak sehat serta dapat mengacaukan stabilitas harga di pasar. Dalam kondisi seperti ini pemerintah mempunyai otoritas untuk memerintahkan para pedagang tersebut agar menaikkan kembali harga barang sesuai dengan harga yang berlaku di pasar.

Menurut Paul R. Krugman dan Maurice obsfeld dalam Karim (2006), dalam praktiknya, dumping baru dipandang sebagai kebijakan perdagangan yang lebih menguntungkan oleh sebuah perusahaan jika ditemukan dua hal, yaitu pertama, industri tersebut bersifat kompetitif tidak sempurna, sehingga perusahaan dapat bertindak sebagai price maker, bukan sebagai price taker; kedua, pasar harus tersegmentasi, sehingga penduduk di dalam negeri tidak dapat dengan mudah membeli barangbarang yang akan diekspor.Sebuah ilustrasi praktik dumping dapat dilihat pada grafik dalamGambar 2.berikut ini : 


\section{Gambar 2. Grafik Dumping}

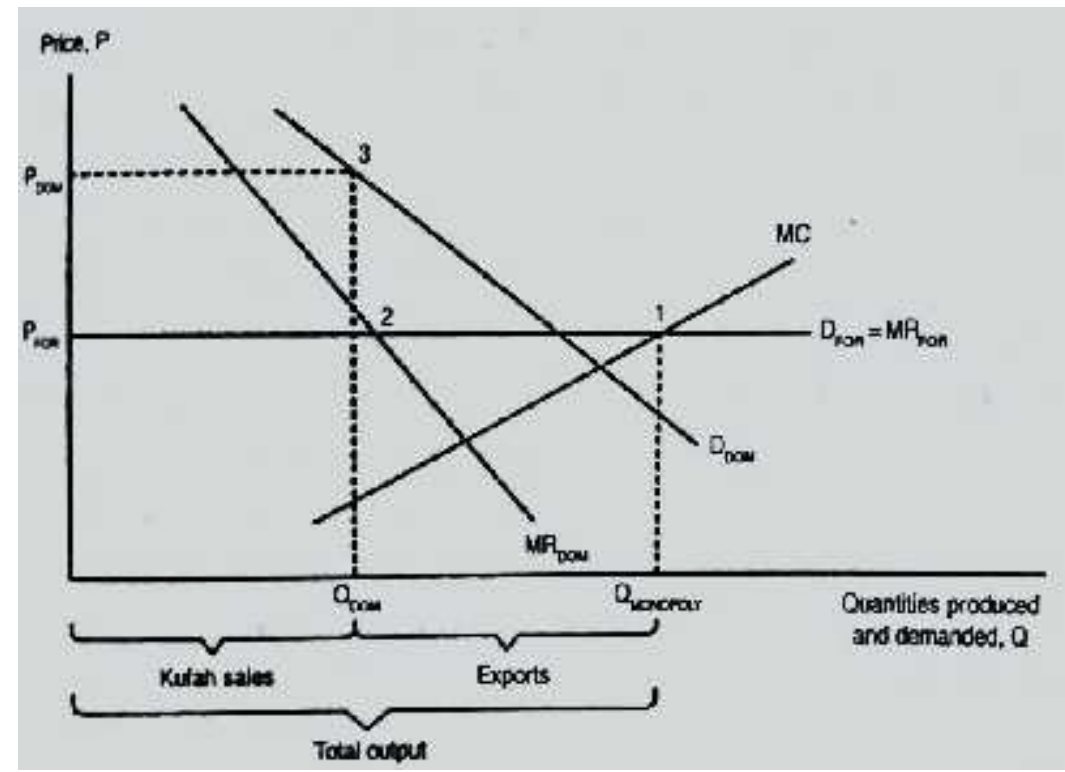

Sumber : Karim, 2006.

Grafik ini menunjukkan sebuah industri yang merupakan satu-satunya perusahaan monopoli dalam negeri. Perusahaan tersebut melakukan penjualan didua pasar, pasar domestik, dalam hal ini kota Kufah yang digambarkan dengan kurva permintaan DDom, dan pasar luar negeri. Di pasar Internasional, kita mengansumsikan bahwa penjulan sangat terkait dengan harga yang ditetapkan oleh perusahaan dan perusahaan tersebt mampu menjual sebanyak yang ia inginkan pada tingkat harga PFor. Garis horizontal $P_{F O R}$ merupakan kurva permintaan terhadap penjualan di pasar Internasioanl. Kita mengansumsikan bahwa pasar telah tersegmentasi sehingga perusahaan tersebut dapat mengenakan harga yang lebih tinggi terhadap barang-barang yang dijual di pasar Internasional. MC adalah kurva marginal cost untuk pengeluaran total yang bisa dijual di pasar manapun.
Untuk

memaksimalkan keuntungan, perusahaan tersebut harus menentukan pendapatan marjin sama dengan marginal cost disetiap pasar. Pendapatan marjin pada penjualan domestikdi ilustrasikan dengan kurva $\mathrm{MR}_{\text {DOM }}$ yang terletak dibawah $\mathrm{D}_{\text {Dом. }}$. Penjualan ekspor menempati harga yang konstan, yakni pada PFor. Dengan demikian, pendapatan marjin (marginal revenue) dari sebuah unit tambahan yang di ekspor adalah hanya sebesar $\mathrm{P}_{\mathrm{FOR}}$. Untuk menentukan marginal cost sama dengan pendapatan marjin (marginal revenue) dikedua pasar tersebut, perusahaan harus memproduksi barang sejumlah Q QмоNopoly, menjual sejumlah Qром di pasar domestik dan melakukan ekspor QMonopoly - QDom. Dalam hal ini biaya produki sebuah unit tambahan adalah sama dengan $P_{F O R}$ yakni pendapatan marjin (marginal revenue) revenue dari penjualan ekspor, yang sama dengan pendapatan marjin (marginal revenue) dari penjualan domestik. Jumlah 
Q tingkat harg $\mathrm{P}_{\mathrm{DOM}}$, yang terletak diatas harga ekspor, $\mathrm{P}_{\mathrm{FOR}}$, dengan demikian perusahaan tersebut melakukan dumping, menjual lebih murah di pasar Internasional daripada di pasar domestik(Karim, 2006).

Dua hal yang membolehkan pemerintah melakukan intervensi terhadap regulasi harga di pasar, yaitu: (a) Para pedagang tidak menjual barang dagangan tertentu (ihtikâr/ Monopoly's Rent-Seeking), padahal masyarakat sangat membutuhkannya, akibat ulah dari sebagian pedagang tersebut, harga di pasar menjadi tidak stabil dan hal tersebut dapat membahayakan kehidupan masyarakat luas dan mencegah terciptanya masyarakat yang sejahtera. Dalam kondisi seperti itu pemerintah dapat melakukan intervensi agar harga barang menjadi normal kembali; dan (b) Sebagian pedagang melakukan praktik siyasah al-ighraq atau banting harga (dumping). Praktik banting harga dapat menimbulkan persaingan yang tidak sehat serta dapat mengacaukan stabilitas harga di pasar. Dalam kondisi seperti ini pemerintah mempunyai otoritas untuk memerintahkan para pedagang tersebut agar menaikkan kembali harga barang sesuai dengan harga yang berlaku di pasar.

Timbulnya kemudharatan terhadap masyarakat merupakan syarat pelarangan penimbunan barang. Apabila hal itu terjadi, barang dagangan hasil timbunan tersebut harus dijual dan keuntungan dari hasil penjualan ini disedekahkan sebagai pendidikan terhadap para pelaku ihtikâr. Adapun para pelaku Ihtikâr itu sendiri hanya berhak mendapatkan modal pokok mereka. Selanjutnya, pemerintah memperingati para pelaku ihtikâr agar tidak mengulangi perbuatannya. Apabila mereka tidak mempedulikan peringatan tersebut, pemerintah berhak menghukum mereka dengan memukul, mengelilingi kota dan memenjarakannya (Azra, 2010). Mekanisme pasar yang sesuai dengan syariah memang tidak mengedepankan intervensi pemerintah pada kondisi pasar berjalan normal. Namun ketika pasar mengalami distorsi yang disebabkan oleh ulah para pelakunya, maka pemerintah tentu perlu membenahi harga untuk mewujudnya kemaslahatan umat. Oleh karena itu, perlu untuk kita ketahui secara komparatif pemikiran-pemikiran tokoh ulama terdahulu tentang mekanisme pasar dan keseimbangan harga pada Tabel 1.1 berikut ini :

Tabel 1. Pemikiran-pemikiran Tokoh Tentang Mekanisme Pasar dan Keseimbangan Harga

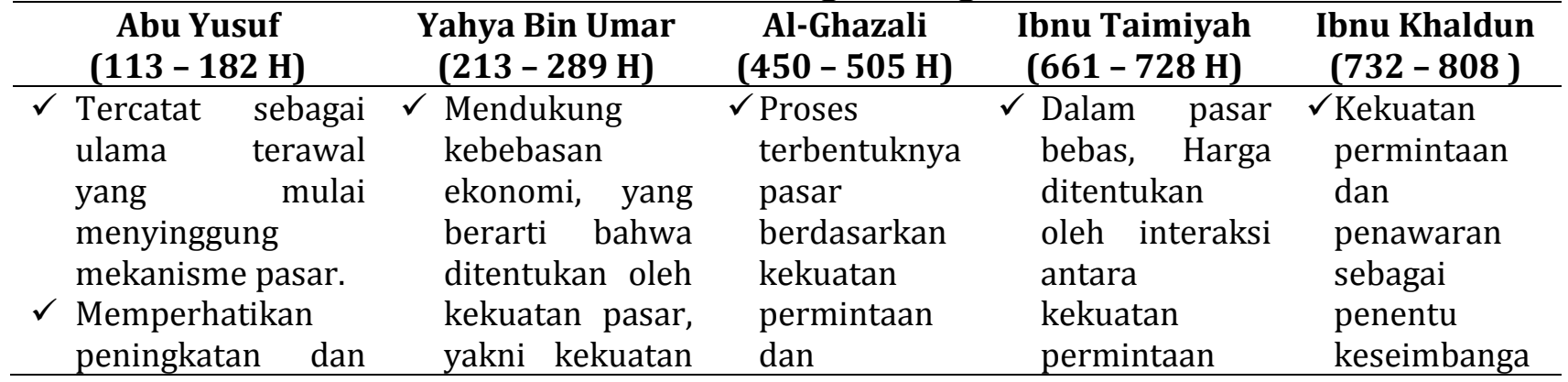




\begin{tabular}{|c|c|c|c|c|c|}
\hline 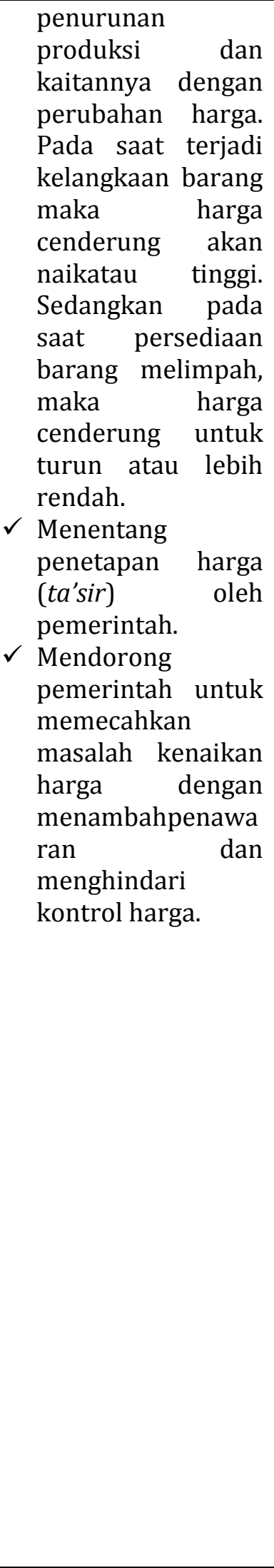 & $\begin{array}{l}\text { penawaran } \\
\text { (supply) dan } \\
\text { permintaan } \\
\text { (demand). } \\
\checkmark \text { Hukum asal } \\
\text { penetapan } \\
\text { harga (ta'sir) } \\
\text { adalah tidak } \\
\text { boleh dilakukan. } \\
\checkmark \text { Pemerintah } \\
\text { tidak boleh } \\
\text { melakukan } \\
\text { intervensi, } \\
\text { kecuali dalam } \\
\text { dua hal, yaitu } \\
\text { (1)Para } \\
\text { pedagang tidak } \\
\text { memperdagang } \\
\text { kan barang } \\
\text { dagangan } \\
\text { tertentunya } \\
\text { yang sangat } \\
\text { dibutuhkan } \\
\text { masyarakat. (2) } \\
\text { para pedagang } \\
\text { melakukan } \\
\text { praktik siyasah } \\
\text { al-ighraq atau } \\
\text { banting harga } \\
\text { (dumping). }\end{array}$ & $\begin{array}{l}\text { penawaran } \\
\text { untuk } \\
\text { menentukan } \\
\text { harga dan } \\
\text { laba. } \\
\checkmark \text { Pasar } \\
\text { merupakan } \\
\text { bagian dari } \\
\text { "keteraturan } \\
\text { alami". } \\
\text { Pentingnya } \\
\text { peran } \\
\text { pemerintah } \\
\text { dalam } \\
\text { menjamin } \\
\text { keamanan } \\
\text { jalur } \\
\text { perdagangan } \\
\checkmark \text { Produk } \\
\text { makanan } \\
\text { sebagai } \\
\text { komoditas } \\
\text { perlu } \\
\text { mendapat } \\
\text { proteksi } \\
\text { pemerintah. } \\
\text { Tidak setuju } \\
\text { dengan } \\
\text { keuntungan } \\
\text { yang berlebih } \\
\text { untuk } \\
\text { menjadi } \\
\text { motivasi } \\
\text { pedagang, } \\
\text { keuntungan } \\
\text { sesungguhny } \\
\text { a adalah } \\
\text { keuntungan } \\
\text { di akhirat } \\
\text { kelak. }\end{array}$ & & $\begin{array}{l}\text { dan } \\
\text { penawaran. } \\
\text { Perekonomian } \\
\text { berdasarkan } \\
\text { pada } \\
\text { mekanisme } \\
\text { pasar dengan } \\
\text { kebebasan } \\
\text { keluar-masuk } \\
\text { pasar dan } \\
\text { harga sepenuhnya } \\
\text { ditentukan } \\
\text { oleh } \\
\text { mekanisme } \\
\text { pasar. } \\
\text { Intervensi } \\
\text { harga oleh } \\
\text { pemerintah } \\
\text { dibenarkan } \\
\text { untuk dan } \\
\text { menegakkan } \\
\text { keadilan serta } \\
\text { memenuhi } \\
\text { kebutuhan } \\
\text { dasar praktik } \\
\text { masyarakat. } \\
\text { Pasar harus } \\
\text { dibersihkan } \\
\text { dari praka } \\
\text { monopoli, } \\
\text { pemalsuan } \\
\text { produk, dan } \\
\text { praktik-praktik } \\
\text { bisnis yang } \\
\text { tidak jujur } \\
\text { lainnya. } \\
\text { Praktik } \\
\text { monopoli } \\
\text { dilarang untuk } \\
\text { menjamin } \\
\text { harga yang adil } \\
\text { bagi } \\
\text { masyarakat. } \\
\text { Pemerintah } \\
\text { tidak perlu ikut } \\
\text { campur tangan } \\
\text { dalam menentukan } \\
\text { mana }\end{array}$ & $\begin{array}{l}\text { n harga. } \\
\checkmark \text { Harga adalah } \\
\text { hasil dari } \\
\text { hukum } \\
\text { permintaan } \\
\text { dan penawaran. } \\
\text { pena suatu } \\
\text { Jika banga } \\
\text { barang langka } \\
\text { dan banyak } \\
\text { diminta, } \\
\text { maka } \\
\text { harganya } \\
\text { tinggi. Jika } \\
\text { suatu barang } \\
\text { berlimpah, } \\
\text { harganya } \\
\text { rendah. } \\
\checkmark \text { Harga suatu } \\
\text { barang terdiri } \\
\text { dari tiga } \\
\text { unsur: Gaji } \\
\text { untuk produsen, } \\
\text { proba untuk } \\
\text { pedagang dan } \\
\text { pajak untuk } \\
\text { pemerintah. }\end{array}$ \\
\hline
\end{tabular}



harga selama
mekanisme
pasar berjalan
normal. Bila
mekanisme
normal tidak
berjalan,
pemerintah
disarankan
melakukan
kontrol harga.

Sumber: Amalia (2010).

Dalam Ekonomi Islam hanya barang/jasa yang dapat mengembangkan dan menopang maslahah sajalah yang dapat dikategorikan sebagai barang/jasa yang mengandung maslahah. Oleh karenanya, dari sudut pandang agama, seorang individu muslim didorong untuk memperoleh atau memproduksi barang/jasa yang mengadung kemaslahatan. Barang/jasa dapat diukur tingkat kemaslahatannya relatif pada kemampuan barang/ jasa tersebut untuk mengembangkan maslahah.

Solusi masalah ihtikâr dan siyasah al-ighraq adalah dengan adanya lembaga otoritas pasar dalam Islam disebut juga dengan lembaga al-Hisbah, diharapkan permasalahan ihtikârdapat ditanggulangi dengan sebaik-baiknya. Al-Hisbah adalah lembaga pengawasan dan peradilan dalam pasar yang eksistensinya sudah ada sejak zaman Rasululah Shallallahu 'Alaihi wa Sallam(Mujahidin,2014). Eksistensi lembaga otoritas pasar Hisbah ini menyiratkan bagaimana perekonomian Islam memandang pasar begitu penting dalam aktivitas ekonomi. Dengan adanya pemberdayaan lembaga al-Hisbah yang baik, diharapkan mampu menanggulangi masalah-masalah yang ada di pasar terutama masalah ihtikârini.
Menurut Mujahidin (2014) Adapun beberapa fungsi al-Hisbah selaku lembaga pengawasan dan peradilan dalam pasar diantaranya adalah sebagai berikut: (a) mengawasi timbangan, ukuran dan harga. Dalam konteks perekonomian kontemporer, Hisbah juga mengawasi standar-standar atau parameterparameter yang menentukan atas barang dan jasa atau bahkan sebuah unit usaha dalam aktifitas ekonomi Islam; (b) mengawasi jual-beli terlarang, praktik riba, maisir, gharar dan penipuan; (c) mengawasi kehalalan, kesehatan dan kebersihan suatu komoditas; (d) pengaturan (tata letak) pasar; (e) mengawasi persengketaan dan ketidakadilan; (f) melakukan intervensi pasar; dan (g) memberikan hukuman terhadap pelanggaran

Kehadiran lembaga-lembaga perbankan dan keuangan syari'ah juga didasarkan kepada maslahah. Inovasi zakat produktif dan waqaf tunai juga didasarkan kepada maslahah. Pendeknya semua aktivitas dan perilaku dalam perekonomian acuannya adalah maslahah. Jika di dalamnya ada kemaslahatan, maka hal itu dibenarkan dan dianjurkan oleh syari'ah. Sebaliknya jika disana ada kemudratan dan mafsadah, maka praktiknya tidak 
dibenarkan, seperti ihtikâr, spekulasi valas dan saham, gharar, judi, dumping, dan segala bisnis yang mengandung riba. Demikian pula dalam membicarakan perilaku konsumen dalam kaitannya dengan utility. Transaksi perbankan syariah juga dilakukan berdasarkan suatu perjanjian yang jelas dan benar serta untuk keuntungan semua pihak tanpa merugikan pihak lain sehingga tidak diperkenankan menggunakan standar ganda harga untuk satu akad serta tidak menggunakan dua transaksi bersamaan yang berkaitan ( $t a^{\prime} a l l u q$ ) dalam satu akad. Syariah tidak membenarkan adanya distorsi harga melalui rekayasa permintaan (najasy), maupun melalui rekayasa penawaran (ihtikâr) serta tidak mengandung unsur kolusi dengan suap menyuap (risywah). Dikarenakan ihtikâr dan siyasah al-ighraq besar kaitannya dengan jual beli, maka kemungkinankemungkinan yang dapat terjadi dalam lembaga keuangan syariah adalah juga besar kaitannya dengan produk-produk yang menggunakan akad jual beli seperti murabahah, salam dan istishna'.

\section{SIMPULAN}

Dalam pandangan Islam jual beli merupakan sarana untuk beribadah kepada Allah dan merupakah fardlu kifayah, oleh karena itu bisnis dan perdagangan (jual beli) tidak boleh lepas dari peran Syari'ah Islamiyah. Sistem Islam melarang setiap aktivitas perekonomian, tak terkecuali jual beli (perdagangan) yang mengandung unsur paksaan, mafsadah (lawan dari manfaat), gharar (penipuan), ihtikâr (penimbunan) dan siyasah al-ighraq (dumping/banting harga) pada masa modern sekarang ini. Konsep jual beli yang dilarang berbagai jenis sesuai dengan cabang-cabangnya dan sifatnya. Hal ini dapat dibagi kedalam: ditinjau dari sudut rusak syarat akad, ditinjau dari sudut rusak syarat sah. Ihtikâr adalah upaya penimbunan barang dagangan untuk menunggu melonjaknya harga. Siyasah al-Ighraq atau banting harga (politik dumping) adalah sebuah aktivitas perdagangan yang bertujuan untuk mencari keuntungan dengan jalan menjual barang pada tingkat harga yang lebih rendah dari harga yang berlaku di pasaran. Para ulama fiqih sepakat meyatakan bahwa ihtikâr dan Siyasah alIghraq tergolong kedalam perbuatan yang dilarang (haram) karena dapat menimbulkan persaingan yang tidak sehat serta dapat mengacaukan stabilitas harga di pasar dan dapat merusak mekanisme pasar.Aktivitas ekonomi merupakan begian yang tak terpisahkan dari ketakwaan seorang muslim kepada Allah Subhanahu wa Ta'ala. Dalam kaitannya dengan masalah ihtikârdan siyasah al-ighraq, kedua istilah ini dalam ilmu ekonomi kontemporer dikenal dengan monopoly's rent-seeking (ihtikâr) dan dumping (siyasah al-ighraq). Dikarenakan ihtikâr dan siyasah al-ighraq besar kaitannya dengan jual beli, maka kemungkinan-kemungkinan yang dapat terjadi dalam lembaga keuangan syariah adalah juga besar kaitannya dengan produk-produk yang menggunakan akad jual beli seperti murabahah, salam dan istishna'.

\section{DAFTAR PUSTAKA}

Al-Jamal, Ibrahim Muhammad. 1986.Kaidah Fiqih. Yogyakarta. Graha Ilmu.

Al-Quranul Karim

Amalia, Euis. 2010.Sejarah Pemikiran Ekonomi Islam Dari Masa Klasik 
Hingga Kontemporer. Depok: Gramata Publishing.

Ayob, Syeikh Hassan. 2008.Fiqh Muamalah. Puchong: Sel. Berlian Publications SDN. BHD.

Azra, Azyumardi. 2010. Sejarah Pemikiran Ekonomi Islam Dari Masa Klasik Hingga Kontemporer. Depok: Gramata Publishing.

Hamid, Syamsul Rijal. 2017. Buku Pintar Agama Islam. Jakarta: Bee Media Pustaka.

Haroen, Nasrun. 2007. Fiqh Muamalah. Jakarta: Gaya Media Pratama.

Karim, Adiwarman Azwar. 2006.Sejarah Pemikiran Ekonomi Islami. Jakarta. PT. RajaGrafindo Persada.

Karim, Adiwarman Azwar. 2008.Ekonomi Mikro Islami. Jakarta: PT. RajaGrafindo Persada.

Mannan, M. Abdul. 1997.Teori Dan Praktek Ekonomi Islam. Yogyakarta: PT. Dana Bhakti Prima Yasa.

Mirzha Ayunirraga dan Qudsi Fauzi. 2015. Peran Komitmen Dalam Menghindari Ihtikar Sembako di Pasar Krembangan Surabaya (Studi Pada Mahasiswa Program Studi Ekonomi Islam Fakultas Ekonomi dan Bisnis Universitas Airlangga,
Jurnal Ekonomi Syarah dan Terapan. Vol. 3, No. 7.

Subhan, Moh. 2015. Pemikiran Ekonomi Yahya Bin Umar Dalam Perspektif Ekonomi Modern, Jurnal Ulumuna, Vol. 1, No. 1.

Mujahidin, Akhmad. Ekonomi Islam 2 : Pasar, Perdagangan, Manajemen, Produksi, Konsumsi, Institusi, Keuangan dan Konstribusi. Pekanbaru: Al-Mujtahadah Press.

Munawwir, Ahmad Warson. 1997. AlMunawwir Kamus Arab - Indonesia. Surabaya: Pustaka Progressif.

Putong, Iskandar. 2003.Ekonomi Mikro Dan Makro. Jakarta: Ghana Indonesia.

Qusthoniah. 2014. Ta'sir Al-Jabari (Penetapan Harga Oleh Negara) Dalam Koridor Fiqh Dengan mempertimbangkan Realitas Ekonomi, Jurnal Syariah. Vol.II, No.II. Shahih Ibn Majah dalam Software Maktabah Syamilah.

Syaikh al-'Allamah Muhammad bin 'Abdurrahman ad-Dimasyqî. 2004. Fiqih Empat Mazhab. Bandung: Hasyimi Press.

Tarmizi, Erwandi. 2014. Harta Haram Muamalat Kontemporer. Bogor:PT. Berkat Mulia Insani. 